\title{
International trade barriers and regional employment: the case of a no-deal Brexit
}

\author{
Hans-Ulrich Brautzsch ${ }^{1}$ and Oliver Holtemöller ${ }^{1,2^{*}}$
}

\section{${ }^{*}$ Correspondence:}

oliver.holtemoeller@iwh-

halle.de

${ }^{2}$ Martin Luther University

Halle-Wittenberg,

06108 Halle (Saale), Germany

Full list of author information

is available at the end of the

article

\begin{abstract}
We use the World Input-Output Database (WIOD) combined with regional sectoral employment data to estimate the potential regional employment effects of international trade barriers. We study the case of a no-deal Brexit in which imports to the United Kingdom (UK) from the European Union (EU) would be subject to tariffs and non-tariff trade costs. First, we derive the decline in UK final goods imports from the EU from industry-specific international trade elasticities, tariffs and non-tariff trade costs. Using input-output analysis, we estimate the potential output and employment effects for 56 industries and 43 countries on the national level. The absolute effects would be largest in big EU countries which have close trade relationships with the UK, such as Germany and France. However, there would also be large countries outside the EU which would be heavily affected via global value chains, such as China, for example. The relative effects (in percent of total employment) would be largest in Ireland followed by Belgium. In a second step, we split up the national effects on the NUTS-2 level for EU member states and additionally on the county (NUTS-3) level for Germany. The share of affected workers varies between $0.03 \%$ and $3.4 \%$ among European NUTS-2 regions and between $0.15 \%$ and $0.4 \%$ among German counties. A general result is that indirect effects via global value chains, i.e., trade in intermediate inputs, are more important than direct effects via final demand.
\end{abstract}

Keywords: Brexit, Employment, European Union, International trade, Tariffs, Trade barriers

JEL Classification: C67, D57, F16, R15

\section{Introduction}

The British people has voted to leave the European Union (EU) by applying article 50 of the Treaty on European Union in June 2016. The United Kingdom (UK) has left the EU on January 31, 2020. However, the UK had still unlimited access to the Single Market until December 31, 2020. For most of the time during the year 2020, it has not been clear whether Brexit will lead to tariffs on trade between the UK and the remaining EU (EU27). Without the last-minute agreement between the EU and the UK of December 24, 2020 (Trade and Cooperation Agreement, TCA), exports from the remaining EU member countries to the UK would have become subject to tariffs according to World Trade Organization standards (WTO-Scenario) as of January 1, 2021.

(c) The Author(s) 2021. This article is licensed under a Creative Commons Attribution 4.0 International License, which permits use, sharing, adaptation, distribution and reproduction in any medium or format, as long as you give appropriate credit to the original author(s) and the source, provide a link to the Creative Commons licence, and indicate if changes were made. The images or other third party material in this article are included in the article's Creative Commons licence, unless indicated otherwise in a credit line to the material. If material is not included in the article's Creative Commons licence and your intended use is not permitted by statutory regulation or exceeds the permitted use, you will need to obtain permission directly from the copyright holder. To view a copy of this licence, visit http://creativeco mmons.org/licenses/by/4.0/. 
We analyze the regional employment effects of tariffs and non-tariff trade barriers. In general, tariffs reduce international trade and result in more unemployment (Furceri et al. 2018) and increase prices for consumers (Amiti et al. 2019). However, sign and magnitude of the effect can depend on the nature and the persistence of the trade shock. In this paper, we add to the literature on employment effects of trade shocks by studying the employment effects in more than 40 countries (both EU member states and other countries) due to increasing trade costs in case of a Brexit, where there is no agreement in place for trade between the UK and the EU (WTO-Scenario). In particular, we show how the regional distribution of the effects within the EU can be estimated using regional sectoral employment data.

The UK is an important trading partner for EU-27 countries. After the U.S., the UK has been the second largest destination outside the EU of goods and services exports from EU-27 countries in 2020 accounting for about 14\% of total EU-27 exports. ${ }^{1}$ A degradation of the trading framework between EU-27 and UK may have important economic consequences on production and employment in EU-27 countries and regions. Because product groups are not all affected in the same way and because of regional agglomeration of production, regions within the EU-27 will face heterogeneous consequences from Brexit. It is important to understand this heterogeneity to develop appropriate policy responses.

If the negotiations between the EU and the UK had failed, a no-deal Brexit would have implied that exports from the remaining EU member countries to the UK would be subject to tariffs. Even without formal tariffs, there are non-tariff trade costs, which consist of organizational cost (waiting, e.g.) at the borders and of substantial paperwork for the producers to document that rules of origin are complied to. Accordingly, the British demand for EU products is likely to decrease due to these trade costs. We study the international potential employment effects of the decline in British import demand. To quantify these effects we take into account that production of final goods depends on intermediate inputs. Not only firms that directly export goods or services to UK are affected by Brexit but also firms that deliver intermediate inputs to these firms. Similar to studies which assess the impact of Brexit on production on the national level, we use input-output analysis in a first stage to quantify the countries and industries that are most affected by a decline in UK import demand from EU-27 due to a no-deal Brexit. Assuming that existing production structures and final goods prices need time to adapt to the changing trade framework between UK and EU-27, input-output analysis can be informative about potential short-term effects due to the decline in UK import demand from EU-27 and thereby complement results from general-equilibrium models which in general are more informative about the long-run.

British firms are also affected themselves due to their participation in global value chains. The results that we report for the UK only refer to the effects of less intermediate input production for foreign firms that export to the UK. It should be stressed that the results that we present are partial effects of a negative trade shock. We do not consider macroeconomic general equilibrium effects. We do not aim to estimate the total effects

\footnotetext{
${ }^{1}$ https://ec.europa.eu/eurostat/statistics-explained/index.php/Extra-EU_trade_in_goods.
} 
of Brexit on employment in the UK or in any other country. Trade diversion is also not considered. Moreover, it is not only international trade in goods and services that will be affected by Brexit. ${ }^{2}$ Overall, our results are more informative for the EU-27 countries than for the UK, because the aspects that are not covered here are much more important for the UK than for the EU-27 countries.

We use the World Input-Output Database (WIOD) to document (i) which industries, (ii) in which countries will be affected most by a decline of British imports from EU member countries and (iii) what the according regional and sectoral employment effects will be. For the EU, we provide a regional breakdown on the NUTS-2 level; for Germany, we additionally provide a detailed regional breakdown on the NUTS-3 (county) level. Chen et al. (2018) also provide a regional breakdown of Brexit exposure on the NUTS-2 level; however, they do not look at employment but only at GDP and labour income, which can be directly inferred from the World Input-Output Database. Our contribution is to combine WIOD with regional and sectoral employment data.

The paper is organized as follows. First, we describe the data and our methodology in Sect. 2. Then, we explain the results by country, by industry and by region in Sect. 3 . Finally, we provide conclusions in Sect. 4.

\section{Conceptual framework}

\subsection{World Input-Output table}

The main data source for our analysis is the World Input-Output Database (WIOD). ${ }^{3}$ We use the 2016 edition (Timmer et al. 2015, Timmer et al. 2016), which covers 43 countries (plus rest of the world) and 56 industries. The countries and the industries are listed in the appendix. We use the most recent available data which refers to the year 2014. Table 1 shows the general structure of the World Input-Output table. Among the 44 (including rest of the world) countries, we distinguish between the $m=27$ countries which remain in the EU, the UK (country $m+1$ ) and $M-m-1$ non-EU countries (including rest of the world).

The matrix $X=\left\{x_{i j}^{k \ell}\right\}$ is called transaction matrix. ${ }^{4}$ Dividing the elements of $X$ by column sums $x^{k \ell}$ yields matrix $A=\left\{\frac{x_{i j}^{k \ell}}{x^{k \ell}}\right\}$. Total output $(x)$ in the $M \times N=44 \times 56=2464$ supply-country-industry combinations can now be written as follows:

$$
x=A x+y,
$$

where the $(M \times N) \times 1$ vector $y=\left\{\sum_{i=1}^{M} y_{i}^{k \ell}\right\}$ denotes final demand in the $M$ countries covered by the 2464 supply-country-industry combinations, respectively. For a given vector of final demand $y$, the corresponding total output vector including the intermediate inputs necessary for production can be recovered:

\footnotetext{
${ }^{2}$ A general overview of studies on the economic impact of Brexit is provided by Bisciari (2019), for example. For early overviews of channels through which Brexit could affect the economy, see Kierzenkowskii et al. (2016), Cumming and Zahra (2016) and Broadbent et al. (2019). Dhingra et al. (2018) discuss foreign direct investment after Brexit, for example, and Powdthavee et al. (2019) the effect of Brexit on subjective well-being. Los et al. (2017) and Dhingra et al. (2017b) discuss local consequences of the Brexit in the UK. Bloom et al. (2019) provide firm-level evidence.

3 http://www.wiod.org/home.

${ }^{4}$ For a general discussion of input-output analysis see Miller and Blair (2009) and for a comprehensive discussion of the analysis of international trade using input-output analysis see Los (2017).
} 


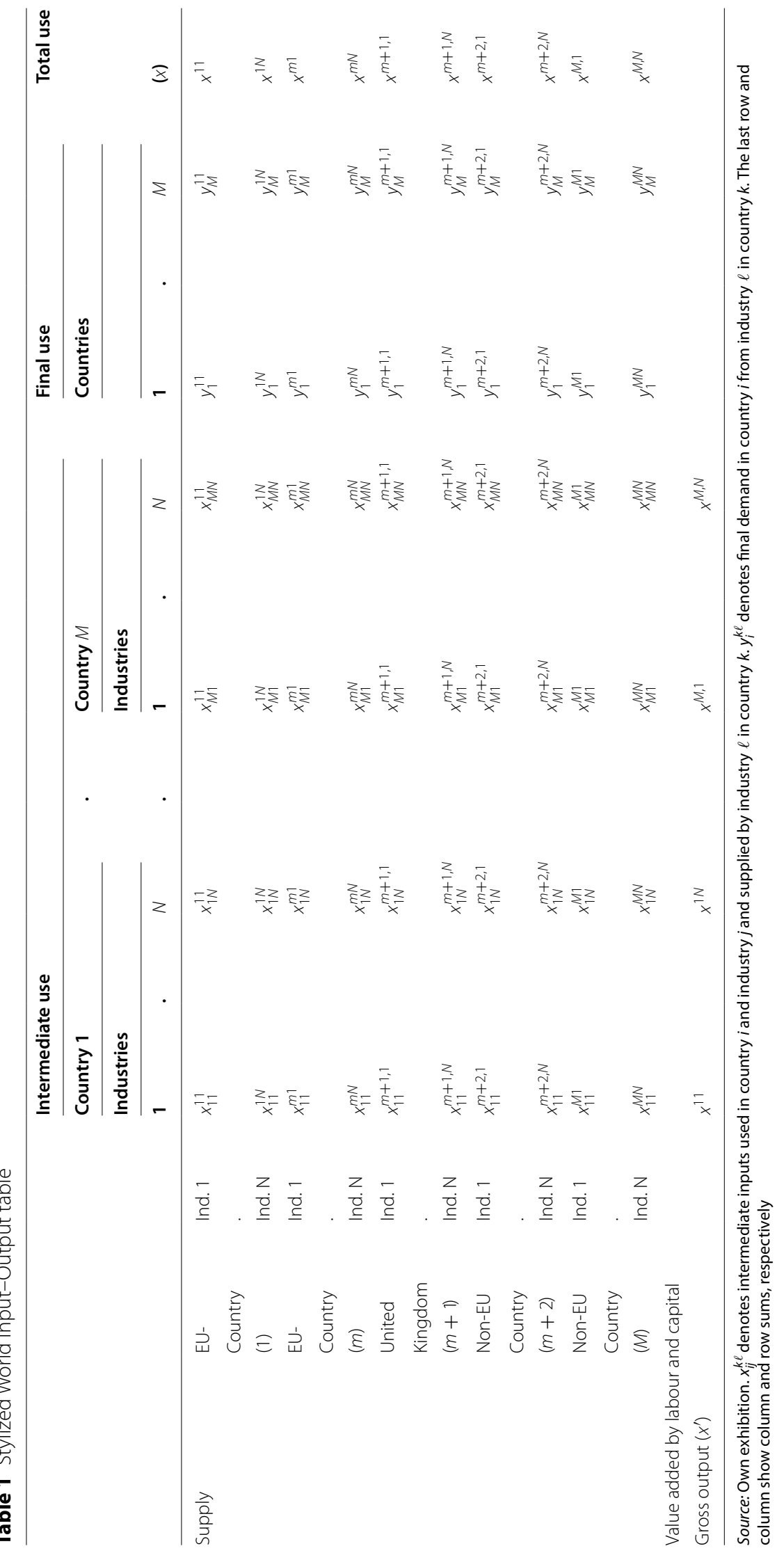



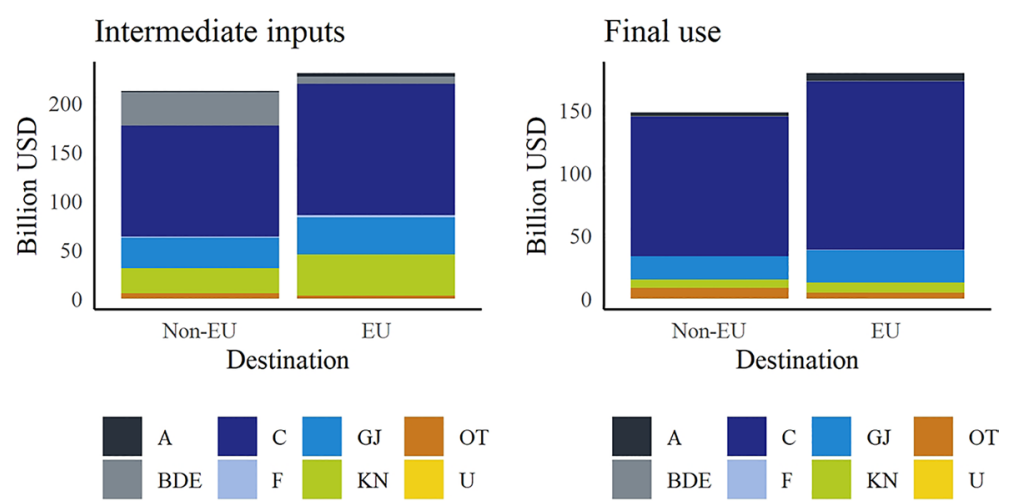

Fig. 1 UK imports from EU and non-EU countries in 2014. Source: World Input-Output Database, data for 2014, and own calculations. NACE sectors are defined in Tables 5 and 6 in the appendix

$$
x=(I-A)^{-1} y,
$$

where $(I-A)^{-1}$ is called inverse Leontief matrix. Accordingly, changes in final demand $\Delta y$ affect total output:

$$
\Delta x=(I-A)^{-1} \Delta y .
$$

\subsection{British final import demand and EU gross output after Brexit}

For both intermediate inputs and final use, the EU is quantitatively the most important trading partner of the UK. Figure 1 shows that the UK imports more goods and services from the EU than from all other trading partners together (exports to the UK by country are reported in Table 7 in the appendix).

The potential consequences of Brexit on British import demand from the remaining EU countries depend on the exit scenario. ${ }^{5}$ Without a formal agreement, trade between the UK and the EU would follow World Trade Organization rules after Brexit. This implies that tariffs would apply between the UK and the EU. Cars and car parts, for example, would be taxed at $10 \%$. Agricultural tariffs are even higher. Average tariffs imposed on final goods imported to the UK are estimated to amount to 8.6\% (Cappariello et al. 2018). Non-tariff costs would also increase. ${ }^{6}$ Higher import prices will lead to less import demand. We use the post-Brexit tariffs, trade elasticities and non-tariff trade barrier estimates provided by Cappariello et al. (2018) and Cappariello et al. (2020) to estimate the country-sector specific trade effects of tariffs and non-tariff trade barriers on final goods imported from the remaining EU countries to the UK. Denote the sector-specific tariff for final goods imports by $\tau_{y}^{\ell}$, the absolute sector-specific trade elasticity by $\epsilon^{\ell}$, and the sector-specific non-tariff trade barrier ad-valorem equivalent by $\mu^{\ell}$

\footnotetext{
${ }^{5}$ IJtsma et al. (2018) provide insights in the position of the UK in global value chains and discuss the implications for the UK's post-Brexit trade policy.

${ }^{6}$ Dhingra et al. (2017a) estimate the increase in non-tariff costs to amount to about $8 \%$ in case of a no-deal Brexit. This figure is also used in the Brexit simulations by Vandenbussche et al. (2019).
} 
$(\ell=1, \ldots, 56)$. Then, the change in final import demand triggered by a no-deal Brexit is given by

$$
\Delta y_{m+1}^{k \ell}=-\left(\epsilon^{\ell} \times \tau_{y}^{\ell}+\frac{\mu^{\ell}}{1+\mu^{\ell}}\right) \times y_{m+1}^{k \ell},
$$

for $k \in\{$ EU-27\}. The according sector-specific percentage reductions in UK imports are provided in Tables 8 and 9 in the appendix. Averaging over all remaining EU countries and all industries, the reduction in UK imports of final demand goods from remaining EU countries amounts to $41 \%$ (see Table 10 in the appendix).

These magnitudes are a little bit lower than the long-run effects reported by Hantzsche et al. (2018) who estimate that a no-deal Brexit would reduce bilateral trade between the UK and the EU by $56 \%$ in the long-run and that about half of this effect would occur immediately. Other estimates of the change in UK imports have a similar order of magnitude; Dhingra et al. (2017a) report a short-run estimate of 34\% (including intermediate inputs) based on a trade model which considers the respective tariffs to be expected in the various industries and Campos and Timini (2019) estimate from a gravity model that trade would drop by $30 \%$. Vandenbussche et al. (2019) also use WIOD data and derive the change in trade flows from sector-specific trade elasticities and the change in (tariff and non-tariff) trade barriers which results in substantially larger effects than our approach.

\subsection{Employment effects}

To quantify the employment effects that are associated with changes in total output $(\Delta x)$ we use employment data from the Social-Economic Accounts provided by the World Input-Output Database. ${ }^{7}$ Similar to Los et al. (2015) and Feenstra and Sasahara (2018), we construct coefficients $b^{k \ell}$ which indicate how many employed persons produce one unit of output in a given industry, using employment by country and industry $\left(n^{k \ell}\right)$ :

$$
b^{k \ell}=\frac{n^{k \ell}}{x^{k \ell}}
$$

and a corresponding $(k \times \ell) \times 1$ vector $b=\left\{b^{k \ell}\right\}$. The change in employment by country and industry triggered by a decline in British final imports from remaining EU member countries including all effects through provision of intermediate inputs is given by:

$$
\Delta b=b * \Delta x,
$$

where $*$ denotes elementwise multiplication.

The employment effect can be decomposed into a direct and an indirect effect. The direct effect refers to the first-round effect of lower British imports without taking into account that affected firms will demand fewer intermediate inputs from other firms. The direct employment effect is then given by

${ }^{7}$ A different approach is followed by Vandenbussche et al. (2019) who apply employment elasticities which measure the drop in employment after a $1 \%$ decrease in value added. 


$$
\Delta b^{D}=b * \Delta y .
$$

Finally, we can calculate the indirect effect:

$$
\Delta b^{\text {Ind }}=\Delta b-\Delta b^{D} .
$$

\subsection{Regional disaggregation}

Using the distribution of employment by industry, we allocate the industry-specific employment effects to the NUTS-2 regions and, for Germany, to its 401 German counties. However, employment by industry and region is only available for more general sectors not for the 56 industries covered by the World Input-Output Database. Employment data for NUTS-2 regions is available for sectors A, B-E, F, G-I, J, K, L, M-N, $\mathrm{O}-\mathrm{Q}, \mathrm{R}-\mathrm{U}$ from Eurostat and for sectors A, B-E, F, G-J, K-N, O-T on the German county level from the working group "Regional Accounts" of the statistical offices of the 16 German states, the Federal Statistical Office and the German Association of Cities and Towns. We group the 56 industries accordingly. ${ }^{8}$

Let the number of affected employed persons in a sub-country region $k$ and industry $\ell$ be denoted by $n^{k \ell}$ and the total number of affected employed persons in the sectors $\mathrm{A}$, $\mathrm{B}-\mathrm{E}, \mathrm{F}, \ldots$ by $n^{\ell \ell}$. Then, the number of affected employed persons in a region is given by

$$
n^{k \ell}=n^{\cdot \ell} \times w^{k \ell},
$$

where $w^{k \ell}$ is the share of region $k$ in total employment in industry $\ell$. Finally, the corresponding share of affected persons in region $k$ is $n^{k \ell} / n^{k}$, where $n^{k}$ denotes total employment in region $k$.

\section{Results and discussion}

\subsection{Output effects by country}

Output effects of the decline in British imports are shown in Table 2. The results fall within the range of previous studies. For Germany, for example, Vandenbussche et al. (2019) estimate a loss in value added due to a no-deal Brexit of $1.76 \%$, while our results indicate a loss in gross output of $0.61 \%$ and in value added of $0.49 \%$, respectively. Felbermayr et al. (2017) discuss the effects of Brexit on individual industries and estimate a no-deal-Brexit-induced decline in German GDP by about $0.2 \%$. Note that direct effects for non-EU countries (including UK) are zero, because the respective trade regimes do not change after Brexit. However, non-EU countries are affected via intermediate inputs delivered to firms in EU countries which export goods and services to the UK.

\subsection{Potential employment effects by country}

If final import demand from the UK declines by $41 \%$ as implied by sector-specific elasticities and increased trading costs, then in total about one million employed persons are affected in 43 countries (without rest of the world), of which only 280,000 persons

\footnotetext{
8 The NUTS-2 level employment data published by Eurostat does not sum up to the same country-industry employment figures in the World Input-Output Database. Therefore, we scale data on the NUTS-2 level by country-industryspecific factors to yield identical sums on the country-industry level for both data sources.
} 
Table 2 Output effects of a decline in UK import demand for final goods from the EU (no-deal Brexit) by country

\begin{tabular}{|c|c|c|c|c|}
\hline \multirow[t]{2}{*}{ Country } & Direct & Indirect & Total & \multirow{2}{*}{$\begin{array}{l}\text { Total } \\
\text { In relation to } \\
\text { value added } \\
\text { (in\%) }\end{array}$} \\
\hline & \multicolumn{3}{|c|}{ In relation to gross output (in \%) } & \\
\hline AUS & 0.00 & 0.01 & 0.01 & 0.01 \\
\hline AUT & 0.10 & 0.21 & 0.31 & 0.24 \\
\hline BEL & 0.46 & 0.37 & 0.83 & 0.62 \\
\hline$B G R$ & 0.07 & 0.16 & 0.23 & 0.20 \\
\hline BRA & 0.00 & 0.02 & 0.02 & 0.01 \\
\hline CAN & 0.00 & 0.01 & 0.01 & 0.01 \\
\hline CHE & 0.00 & 0.08 & 0.08 & 0.07 \\
\hline $\mathrm{CHN}$ & 0.00 & 0.02 & 0.02 & 0.01 \\
\hline CYP & 0.15 & 0.44 & 0.59 & 0.47 \\
\hline CZE & 0.26 & 0.42 & 0.68 & 0.52 \\
\hline DEU & 0.29 & 0.32 & 0.61 & 0.49 \\
\hline DNK & 0.28 & 0.26 & 0.54 & 0.39 \\
\hline ESP & 0.21 & 0.24 & 0.45 & 0.31 \\
\hline EST & 0.06 & 0.12 & 0.18 & 0.16 \\
\hline FIN & 0.04 & 0.11 & 0.16 & 0.12 \\
\hline FRA & 0.18 & 0.22 & 0.40 & 0.30 \\
\hline GBR & 0.00 & 0.08 & 0.08 & 0.07 \\
\hline GRC & 0.06 & 0.06 & 0.13 & 0.11 \\
\hline HRV & 0.09 & 0.13 & 0.22 & 0.21 \\
\hline HUN & 0.22 & 0.34 & 0.56 & 0.42 \\
\hline IDN & 0.00 & 0.02 & 0.02 & 0.01 \\
\hline IND & 0.00 & 0.01 & 0.01 & 0.01 \\
\hline $\mathrm{IRL}$ & 1.82 & 0.56 & 2.38 & 1.87 \\
\hline ITA & 0.15 & 0.24 & 0.38 & 0.29 \\
\hline JPN & 0.00 & 0.01 & 0.01 & 0.01 \\
\hline KOR & 0.00 & 0.03 & 0.03 & 0.02 \\
\hline LTU & 0.11 & 0.15 & 0.27 & 0.22 \\
\hline LUX & 0.15 & 0.34 & 0.50 & 0.39 \\
\hline LVA & 0.06 & 0.13 & 0.19 & 0.16 \\
\hline MEX & 0.00 & 0.01 & 0.01 & 0.01 \\
\hline MLT & 4.25 & 1.73 & 5.98 & 5.09 \\
\hline NLD & 0.29 & 0.34 & 0.63 & 0.51 \\
\hline NOR & 0.00 & 0.08 & 0.08 & 0.08 \\
\hline POL & 0.23 & 0.35 & 0.58 & 0.50 \\
\hline PRT & 0.17 & 0.20 & 0.37 & 0.26 \\
\hline $\mathrm{ROU}$ & 0.09 & 0.18 & 0.28 & 0.24 \\
\hline RUS & 0.00 & 0.04 & 0.04 & 0.04 \\
\hline SVK & 0.44 & 0.46 & 0.90 & 0.64 \\
\hline SVN & 0.06 & 0.20 & 0.26 & 0.21 \\
\hline SWE & 0.11 & 0.19 & 0.30 & 0.25 \\
\hline TUR & 0.00 & 0.06 & 0.06 & 0.05 \\
\hline TWN & 0.00 & 0.04 & 0.04 & 0.03 \\
\hline USA & 0.00 & 0.02 & 0.02 & 0.02 \\
\hline EU-27 & 0.25 & 0.27 & 0.53 & 0.40 \\
\hline
\end{tabular}

The table shows estimated direct and indirect output effects of a decline in British final goods imports due to tariffs and non-tariff trade costs after a no-deal Brexit derived from input-output analysis. General-equilibrium effects and other relevant channels such as trade diversion are not included. Source: World Input-Output Database, data for 2014, own calculations 


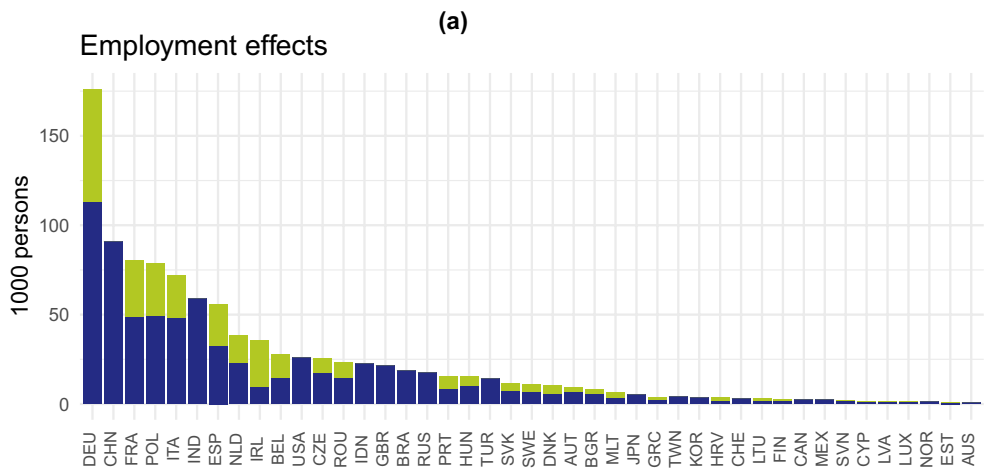

(b)

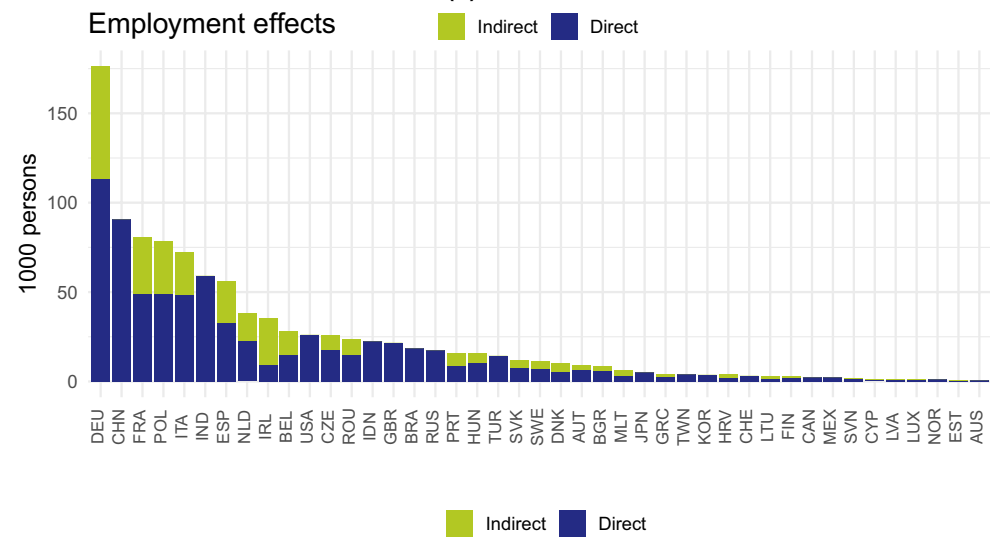

Fig. 2 Potential employment effects of a decline in UK import demand for final goods from the EU (no-deal Brexit). a Absolute effect and $\mathbf{b}$ Relative effect. The figures shows estimated direct and indirect employment effects of a decline in British final goods imports due to tariffs and non-tariff trade costs after a no-deal Brexit derived from input-output analysis. General-equilibrium effects and other relevant channels such as trade diversion are not included. Source: World Input-Output Database, data for 2014, and own calculations

in firms within the European Union that directly export final goods to the UK. About 730,000 persons will be affected by second-round effects that hit firms delivering intermediate inputs.

The overall effect on absolute employment is largest for Germany (Fig. 2a), where about 176,000 persons are potentially affected (see also Table 3 ).

The absolute effect is also relatively large for China (about 91,000 persons) although there are no direct effects, because China is not a member country of the EU. However, China will be affected via intermediate inputs of firms that export to the UK. Relative to total employment, Malta and Ireland are heavily affected. In these two countries, exports to the UK amount to $13.5 \%$ (Malta) and 7.3\% (Ireland) of total production (see Table 7 in the appendix). In Malta, the reduction of trade with the UK may potentially affect $3.4 \%$ and in Ireland $1.9 \%$ of all employed persons (Fig. $2 \mathrm{~b}$ ).

Overall, the variation in the relative employment effects is mainly driven by the heterogeneity in the output effects: in a scatter plot (Fig. 3) of relative total-output effect and relative employment effect, the observations lie very close to a fitted regression line.

In countries above the regression line, the employment effect is relatively large compared to the output effect; this implies that the affected sectors exhibit a relatively low labor productivity. On the other hand, in countries below the regression line, labor 
Table 3 Potential employment effects of a decline in UK import demand for final goods from the EU (no-deal Brexit)

\begin{tabular}{|c|c|c|c|c|c|c|c|}
\hline \multirow[t]{2}{*}{ Country } & \multicolumn{3}{|c|}{ Affected persons } & \multirow{2}{*}{$\begin{array}{l}\text { Total } \\
\text { Employment } \\
\text { (1000 pers.) }\end{array}$} & \multicolumn{3}{|c|}{ Share of affected persons } \\
\hline & $\begin{array}{l}\text { Direct (1000 } \\
\text { pers.) }\end{array}$ & $\begin{array}{l}\text { Indirect } \\
(1000 \\
\text { pers.) }\end{array}$ & $\begin{array}{l}\text { Sum }(1000 \\
\text { pers.) }\end{array}$ & & Direct (\%) & Indirect (\%) & Sum (\%) \\
\hline AUS & 0.000 & 0.751 & 0.751 & 11,863 & 0.000 & 0.006 & 0.006 \\
\hline AUT & 2.773 & 6.624 & 9.397 & 4268 & 0.065 & 0.155 & 0.220 \\
\hline BEL & 13.338 & 14.837 & 28.175 & 4547 & 0.293 & 0.326 & 0.620 \\
\hline$B G R$ & 2.401 & 5.857 & 8.258 & 3602 & 0.067 & 0.163 & 0.229 \\
\hline BRA & 0.000 & 18.711 & 18.711 & 104,029 & 0.000 & 0.018 & 0.018 \\
\hline CAN & 0.000 & 2.298 & 2.298 & 18,449 & 0.000 & 0.012 & 0.012 \\
\hline $\mathrm{CHE}$ & 0.000 & 3.129 & 3.129 & 5084 & 0.000 & 0.062 & 0.062 \\
\hline $\mathrm{CHN}$ & 0.000 & 90.862 & 90.862 & 858,368 & 0.000 & 0.011 & 0.011 \\
\hline CYP & 0.431 & 1.082 & 1.513 & 357 & 0.121 & 0.303 & 0.424 \\
\hline CZE & 7.906 & 17.813 & 25.719 & 5111 & 0.155 & 0.349 & 0.503 \\
\hline DEU & 63.068 & 113.281 & 176.349 & 42,706 & 0.148 & 0.265 & 0.413 \\
\hline DNK & 4.505 & 5.805 & 10.310 & 2765 & 0.163 & 0.210 & 0.373 \\
\hline ESP & 23.463 & 32.456 & 55.918 & 17,966 & 0.131 & 0.181 & 0.311 \\
\hline EST & 0.411 & 0.572 & 0.983 & 620 & 0.066 & 0.092 & 0.159 \\
\hline FIN & 0.726 & 2.091 & 2.818 & 2502 & 0.029 & 0.084 & 0.113 \\
\hline FRA & 31.536 & 49.104 & 80.640 & 27,295 & 0.116 & 0.180 & 0.295 \\
\hline GBR & 0.000 & 21.754 & 21.754 & 30,726 & 0.000 & 0.071 & 0.071 \\
\hline GRC & 1.622 & 2.378 & 4.000 & 3965 & 0.041 & 0.060 & 0.101 \\
\hline HRV & 1.848 & 1.887 & 3.736 & 1569 & 0.118 & 0.120 & 0.238 \\
\hline HUN & 5.420 & 10.251 & 15.671 & 4235 & 0.128 & 0.242 & 0.370 \\
\hline IDN & 0.000 & 22.484 & 22.484 & 168,808 & 0.000 & 0.013 & 0.013 \\
\hline IND & 0.000 & 59.128 & 59.128 & 658,776 & 0.000 & 0.009 & 0.009 \\
\hline $\mathrm{IRL}$ & 26.168 & 9.356 & 35.524 & 1914 & 1.367 & 0.489 & 1.856 \\
\hline ITA & 23.917 & 48.262 & 72.179 & 24,371 & 0.098 & 0.198 & 0.296 \\
\hline JPN & 0.000 & 5.112 & 5.112 & 61,232 & 0.000 & 0.008 & 0.008 \\
\hline KOR & 0.000 & 3.861 & 3.861 & 24,446 & 0.000 & 0.016 & 0.016 \\
\hline LTU & 1.148 & 1.738 & 2.886 & 1319 & 0.087 & 0.132 & 0.219 \\
\hline LUX & 0.367 & 0.996 & 1.364 & 403 & 0.091 & 0.247 & 0.338 \\
\hline LVA & 0.411 & 1.019 & 1.430 & 900 & 0.046 & 0.113 & 0.159 \\
\hline MEX & 0.000 & 2.283 & 2.283 & 38,997 & 0.000 & 0.006 & 0.006 \\
\hline MLT & 3.296 & 3.181 & 6.478 & 190 & 1.735 & 1.674 & 3.409 \\
\hline NLD & 15.484 & 22.897 & 38.381 & 8727 & 0.177 & 0.262 & 0.440 \\
\hline NOR & 0.000 & 1.137 & 1.137 & 2747 & 0.000 & 0.041 & 0.041 \\
\hline $\mathrm{POL}$ & 29.122 & 49.445 & 78.567 & 15,577 & 0.187 & 0.317 & 0.504 \\
\hline PRT & 7.133 & 8.543 & 15.676 & 4546 & 0.157 & 0.188 & 0.345 \\
\hline $\mathrm{ROU}$ & 8.423 & 14.844 & 23.267 & 8805 & 0.096 & 0.169 & 0.264 \\
\hline RUS & 0.000 & 17.501 & 17.501 & 74,286 & 0.000 & 0.024 & 0.024 \\
\hline SVK & 4.158 & 7.418 & 11.577 & 2227 & 0.187 & 0.333 & 0.520 \\
\hline SVN & 0.438 & 1.490 & 1.928 & 941 & 0.047 & 0.158 & 0.205 \\
\hline SWE & 4.044 & 7.045 & 11.090 & 4750 & 0.085 & 0.148 & 0.233 \\
\hline TUR & 0.000 & 14.249 & 14.249 & 32,326 & 0.000 & 0.044 & 0.044 \\
\hline TWN & 0.000 & 3.998 & 3.998 & 20,207 & 0.000 & 0.020 & 0.020 \\
\hline USA & 0.000 & 26.222 & 26.222 & 155,769 & 0.000 & 0.017 & 0.017 \\
\hline EU-27 & 283.556 & 440.273 & 723.832 & 196,178 & 0.145 & 0.224 & 0.367 \\
\hline
\end{tabular}

The table shows estimated direct and indirect output effects of a decline in British final goods imports due to tariffs and non-tariff trade costs after a no-deal Brexit derived from input-output analysis. General-equilibrium effects and other relevant channels such as trade diversion are not included. Source: World Input-Output Database, data for 2014, own calculations 


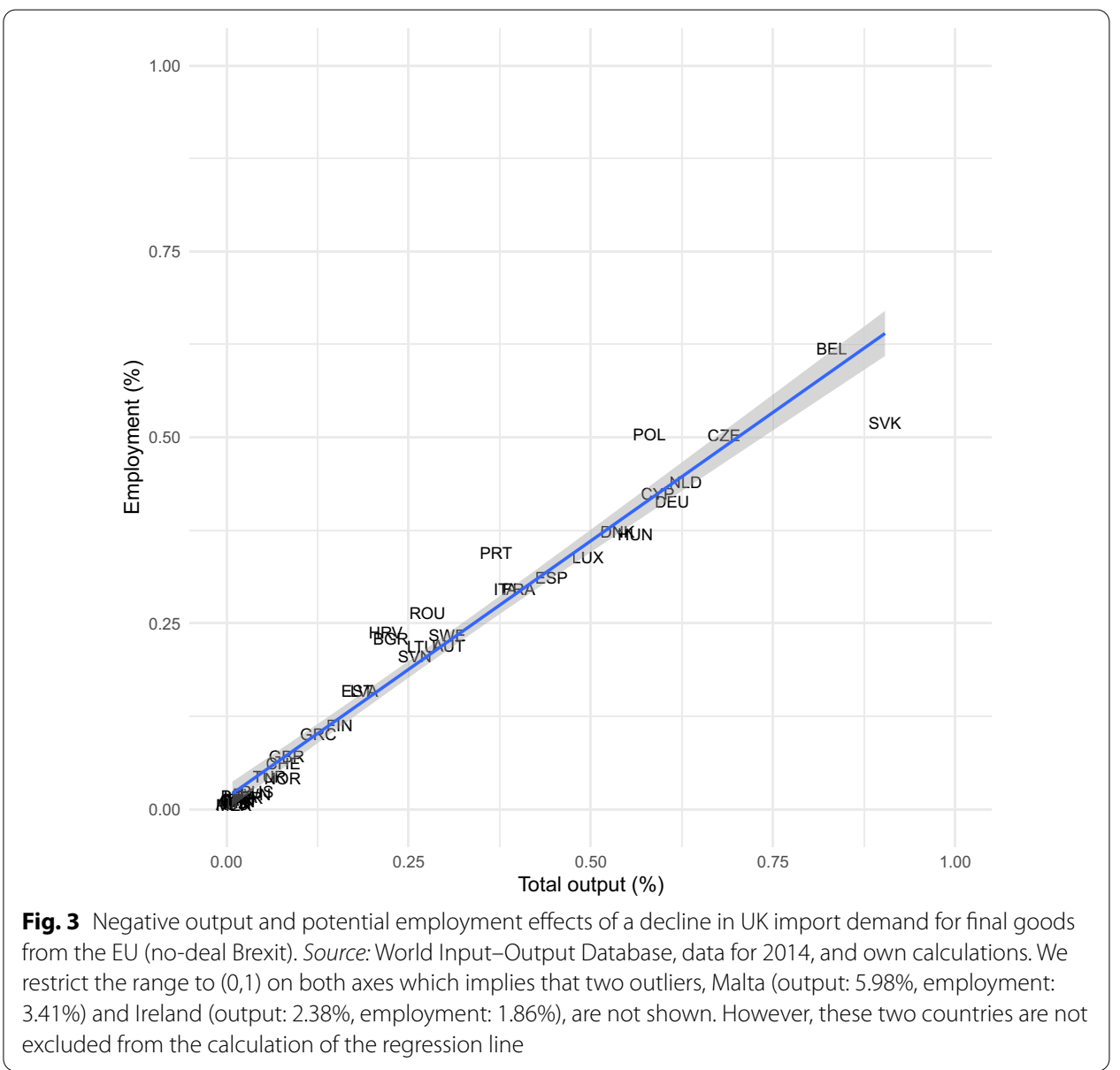

productivity in affected sectors is high, as in Slovakia, for example, where manufacturing of cars is the most affected sector.

\subsection{Potential employment effects by industry}

Which industries are affected most varies from country to country (see Table 11 in the appendix). Figure 4 shows country-specific heat maps of the employment effects. Light colored squares indicate that the effect is relatively small in an industry, while dark colored squares indicate a relatively large effect (based on the absolute total employment effect by country and industry).

In some countries, such as Bulgaria or Brazil, for example, agriculture is heavily affected. In other countries, such as Czech Republic and Germany, the effects are largest in manufacturing industries. In France and in the Netherlands, wholesale trade shows the strongest exposure. In the United States, administrative and support services are strongly affected. Note that the UK itself is also affected due to intermediate inputs exported by UK firms to non-UK firms which deliver to firms exporting from the remaining EU to the UK directly or indirectly via global value chains. 


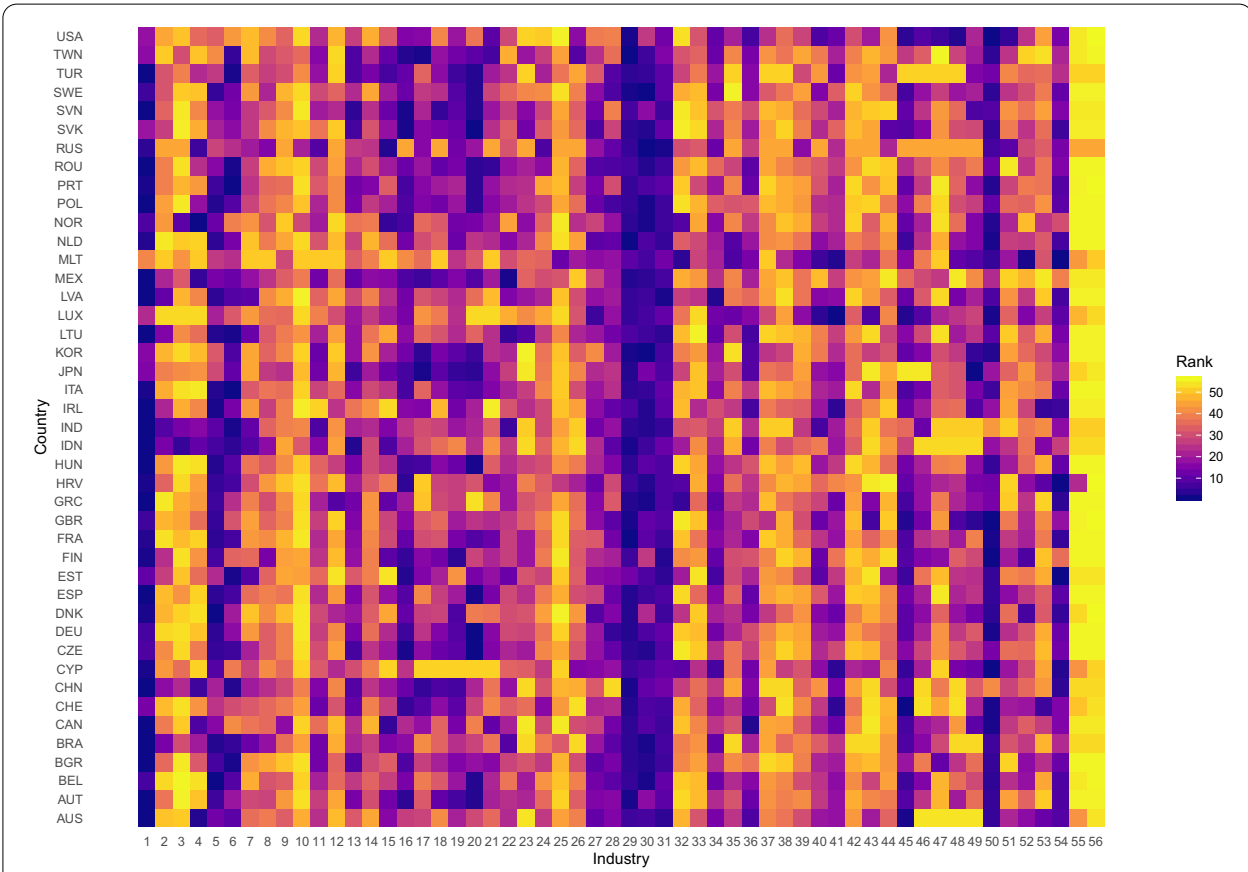

Fig. 4 Absolute total potential employment effects of a decline in UK import demand for final goods from the EU (no-deal Brexit) by country and industry. Light color: relative small effect, dark color: relative large effect. Based on ranked absolute total (direct and indirect) employment effects by country of a decline in British final goods imports due to tariffs and non-tariff trade costs after a no-deal Brexit derived from inputoutput analysis. General-equilibrium effects and other relevant channels such as trade diversion are not included. Source: World Input-Output Database, data for 2014, and own calculations

The industry-specific relative effects are large in Belgium, Malta and Ireland. While many sectors are strongly affected in Ireland and Malta, manufacturing is strongly affected in Belgium (manufacturing of cars $7.5 \%$, textiles $4.2 \%$, other transport equipment 4.0\%). In most other countries, relative effects are large in some specific industries, such as the car industry in Germany (3.2\%) and Spain (3.6\%) or manufacturing of textiles in the Netherlands (3.8\%) and in Sweden (3.3\%). ${ }^{9}$

\subsection{Regional employment effects}

The share of affected workers if final import demand by the UK decreases due to a no-deal Brexit varies between $0.03 \%$ and 3.4\% among European NUTS-2 regions and between $0.15 \%$ and $0.4 \%$ among German counties. Besides Malta and the regions in Ireland, Belgian provinces, the region Západné Slovensko (sector B-E) in the Slovak Republic, the regions Severovýchod (B-E), Strední Morava (B-E) and Jihozápad (B-E) in the Czech Republic as well as regions in Poland exhibit a relatively large employment exposure (see Table 12 in the appendix). Overall, while in Malta, Ireland, Belgium, Slovak Republic and Poland almost the whole country exhibits a similar exposure, the effects are more concentrated in some regions in Italy and Spain, see Fig. 5.

Within Germany, the county which is affected most in terms of relative employment effect is Dingolfing-Landau (449 of about 67,000 employed persons) followed

\footnotetext{
${ }^{9}$ Aichele and Felbermayr (2015) also find that the car industry is the most-affected industry in Germany.
} 


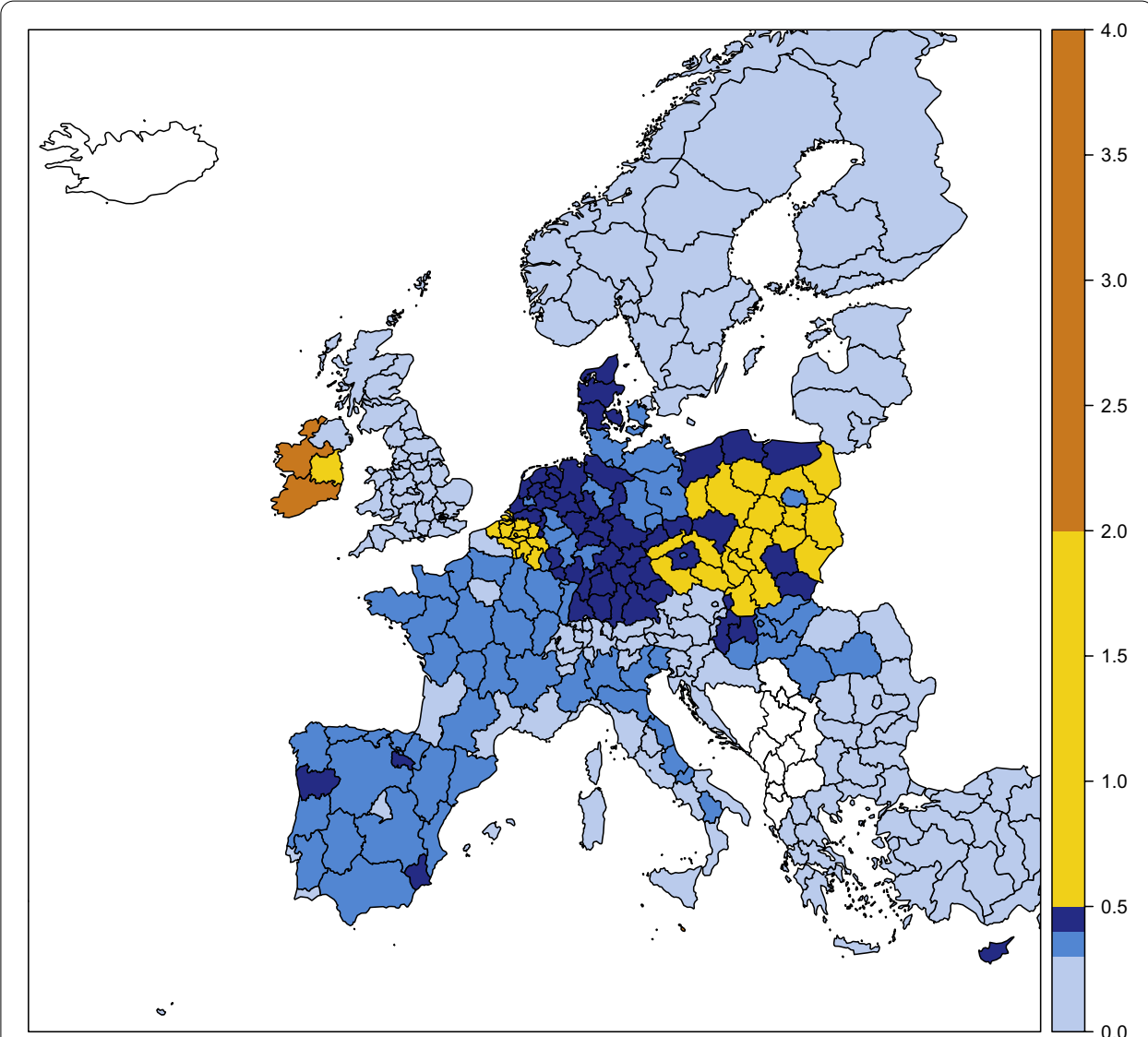

Fig. 5 Potential regional employment effect of a decline in UK import demand for final goods from the EU (no-deal Brexit) in European NUTS-2 regions. Employment effect in relation to total employment by region in percent. Source: World Input-Output Database, Eurostat (regional employment data) and own calculations. EuroGeographics for the administrative boundaries. Cuts in the color code at $\{0.3,0.4,0.5,2.0\}$.

by Wolfsburg ( 835 of about 127,000 employed persons), see Table 13. The distribution across German counties is depicted in Fig. 6.

Overall, counties such as Wolfsburg (Volkswagen) or Dingolfing-Landau (BMW) in which production and trade of cars and car parts are relatively important are affected more than other counties.

\section{Conclusions}

Tariffs and non-tariff trade barriers make internationally traded products more expensive. Therefore, the demand for foreign products decreases if tariffs are introduced. We analyze the regional employment effects of tariffs and non-tariff trade barriers on trade between the UK and the EU after a no-deal Brexit. If the UK had left the EU without an agreement on international trade in goods and services many countries would have been affected by the corresponding decline in exports to the UK. Since production is organized in global value chains, not only would firms in the remaining EU countries suffer from declining exports to the UK, but also firms that supply intermediate inputs to firms that deliver final goods to the UK. The international integration of trade can be disentangled using World Input-Output tables. If 


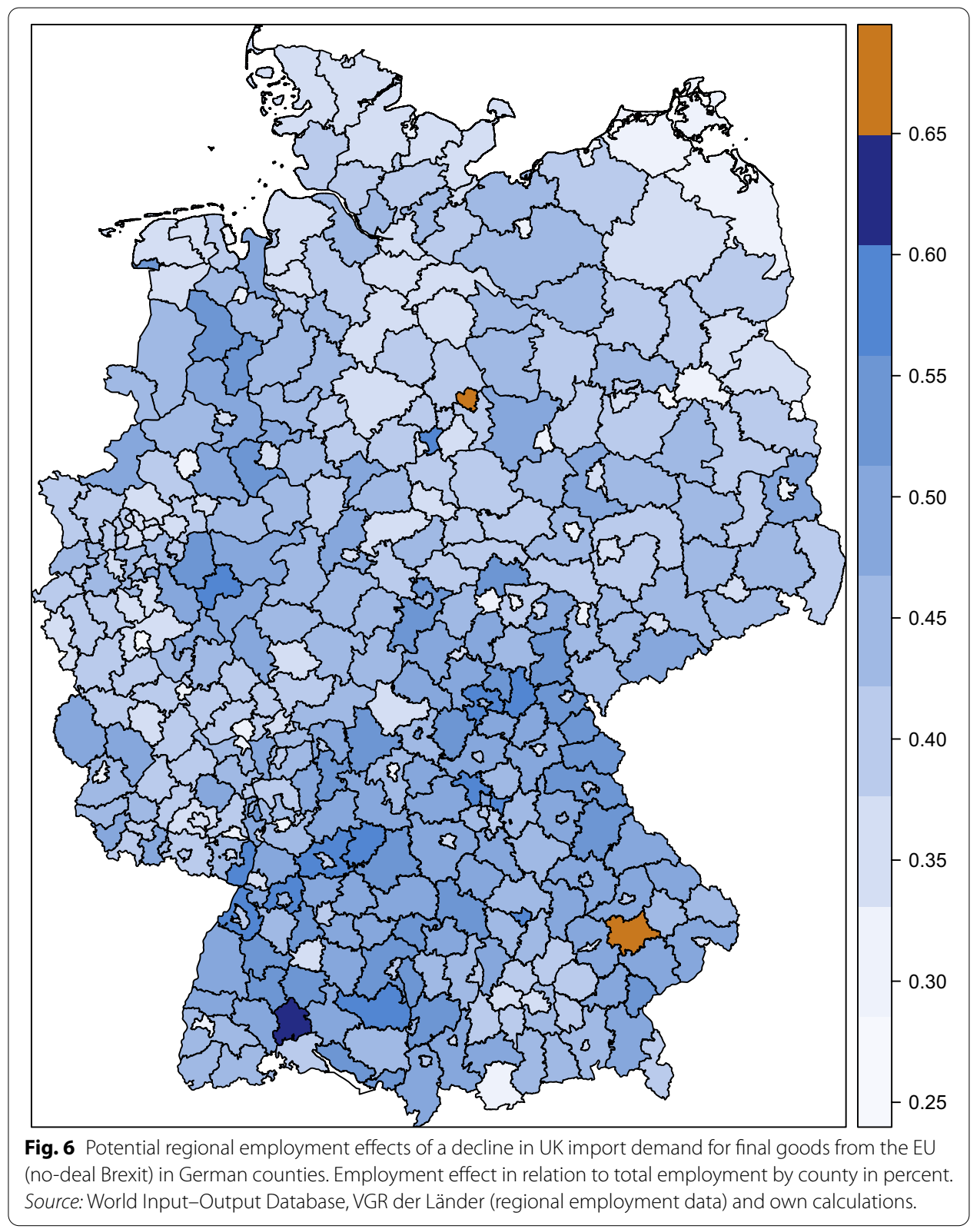

final import demand from the UK declines by $41 \%$ as implied by sector-specific elasticities and increased trading costs, then in total about one million employed persons are affected in 43 countries (without rest of the world), of which only 280,000 persons in firms within the European Union that directly export final goods to the UK. About 730,000 persons would be be affected by second-round effects that hit firms delivering intermediate inputs.

The motor vehicle industry would be the most affected industry (both manufacture and trade). In Germany alone, about 35,600 persons in the motor vehicle industry (2.1\% of total employment in motor vehicle manufacturing and trade) would be directly or indirectly affected. Accordingly, within Germany important motor vehicle 
manufacturing places would be most exposed to employment risks after a no-deal Brexit. However, there would also be considerable absolute effects in non-EU countries, such as China or India. The relative effect (in relation to total employment) in these countries would be rather low.

Our quantitative effects depend crucially on the assumption about the decline in UK final demand from the EU. The actual decline can be smaller or larger than assumed here. The results from the input-output analysis are linear in the size of the initial shock. If the decline in UK final demand from the EU is smaller, then our absolute figures and shares in total employment have to be adjusted proportionally. The relative distribution of the effects over countries and industries, however, would be unaffected by this. This also holds true for the regional distribution within countries.

\section{Appendix}

See Tables 4, 5, 6, 7, 8, 9, 10, 11, 12, 13 .

Table 4 Countries in the World Input-Output Database

\begin{tabular}{llllll}
\hline Acronym & Country & Acronym & Country & Acronym & Country \\
\hline AUS & Australia & FRA & France* & MLT & Malta* $^{*}$ \\
AUT & Austria* & GBR & United Kingdom & NLD & Netherlands* $^{*}$ \\
BEL & Belgium* & GRC & Greece* & NOR & Norway \\
BGR & Bulgaria* & HRV & Croatia* & POL & Poland* \\
BRA & Brazil & HUN & Hungary* & PRT & Portugal* \\
CAN & Canada & IND & India & ROU & Romania* \\
CHE & Switzerland & IDN & Indonesia & RUS & Russian Federation \\
CHN & China & IRL & Ireland* & SVK & Slovakia* \\
CYP & Cyprus* & ITA & Italy* & SVN & Slovenia* \\
CZE & Czech Republic* & JPN & Japan & SWE & Sweden* \\
DEU & Germany* & KOR & South Korea & TUR & Turkey \\
DNK & Denmark* & LTU & Lithuania* & TWN & Taiwan \\
ESP & Spain* & LUX & Luxembourg* & USA & United States \\
EST & Estonia* & LVA & Latvia* & & \\
FIN & Finland* & MEX & Mexico & & \\
\hline
\end{tabular}

Remaining EU member countries after Brexit are marked by an asterisk 
Table 5 Industry classification (A-F)

\begin{tabular}{|c|c|c|}
\hline No. & NACE Code & Description \\
\hline & $A$ & Agriculture, forestry and fishing \\
\hline 1 & $\mathrm{~A} 01$ & Crop and animal production, hunting and related service activities \\
\hline 2 & $\mathrm{~A} 02$ & Forestry and logging \\
\hline \multirow[t]{2}{*}{3} & A03 & Fishing and aquaculture \\
\hline & $B, C, D, E$ & Manufacturing, mining and quarrying and other industry \\
\hline 4 & B & Mining and quarrying \\
\hline 5 & $\mathrm{C} 10-\mathrm{C} 12$ & Manufacture of food products, beverages and tobacco products \\
\hline 6 & $\mathrm{C} 13-\mathrm{C} 15$ & Manufacture of textiles, wearing apparel and leather products \\
\hline 7 & C16 & $\begin{array}{l}\text { Manufacture of wood and of products of wood and cork, except furniture; } \\
\text { manufacture of articles of straw and plaiting materials }\end{array}$ \\
\hline 8 & $\mathrm{C} 17$ & Manufacture of paper and paper products \\
\hline 9 & $\mathrm{C} 18$ & Printing and reproduction of recorded media \\
\hline 10 & C19 & Manufacture of coke and refined petroleum products \\
\hline 11 & $\mathrm{C} 20$ & Manufacture of chemicals and chemical products \\
\hline 12 & C21 & Manufacture of basic pharmaceutical products and pharmaceutical preparations \\
\hline 13 & $\mathrm{C} 22$ & Manufacture of rubber and plastic products \\
\hline 14 & $\mathrm{C} 23$ & Manufacture of other non-metallic mineral products \\
\hline 15 & C24 & Manufacture of basic metals \\
\hline 16 & $\mathrm{C} 25$ & Manufacture of fabricated metal products, except machinery and equipment \\
\hline 17 & C26 & Manufacture of computer, electronic and optical products \\
\hline 18 & $\mathrm{C} 27$ & Manufacture of electrical equipment \\
\hline 19 & $\mathrm{C} 28$ & Manufacture of machinery and equipment n.e.c. \\
\hline 20 & C29 & Manufacture of motor vehicles, trailers and semi-trailers \\
\hline 21 & C30 & Manufacture of other transport equipment \\
\hline 22 & C31_C32 & Manufacture of furniture; other manufacturing \\
\hline 23 & C33 & Repair and installation of machinery and equipment \\
\hline 24 & D35 & Electricity, gas, steam and air conditioning supply \\
\hline 25 & E36 & Water collection, treatment and supply \\
\hline \multirow[t]{2}{*}{26} & E37-E39 & $\begin{array}{l}\text { Sewerage; waste collection, treatment and disposal activities; materials recovery; } \\
\text { remediation activities and other waste management services }\end{array}$ \\
\hline & F & Construction \\
\hline 27 & $\mathrm{~F}$ & Construction \\
\hline
\end{tabular}

Source: European Commission (2008) 
Table 6 Industry classification ( $G-U$ )

\begin{tabular}{|c|c|c|}
\hline No. & NACE code & Description \\
\hline & $G-T$ & Trade and services \\
\hline 28 & G45 & Wholesale and retail trade and repair of motor vehicles and motorcycles \\
\hline 29 & G46 & Wholesale trade, except of motor vehicles and motorcycles \\
\hline 30 & G47 & Retail trade, except of motor vehicles and motorcycles \\
\hline 31 & $\mathrm{H} 49$ & Land transport and transport via pipelines \\
\hline 32 & $\mathrm{H} 50$ & Water transport \\
\hline 33 & $\mathrm{H} 51$ & Air transport \\
\hline 34 & $\mathrm{H} 52$ & Warehousing and support activities for transportation \\
\hline 35 & $\mathrm{H} 53$ & Postal and courier activities \\
\hline 36 & । & Accommodation and food service activities \\
\hline 37 & $J 58$ & Publishing activities \\
\hline 38 & J59_J60 & $\begin{array}{l}\text { Motion picture, video and television programme production, sound recording and music } \\
\text { publishing activities; programming and broadcasting activities }\end{array}$ \\
\hline 39 & J61 & Telecommunications \\
\hline 40 & J62_J63 & Computer programming, consultancy and related activities; information service activities \\
\hline 41 & K64 & Financial service activities, except insurance and pension funding \\
\hline 42 & K65 & Insurance, reinsurance and pension funding, except compulsory social security \\
\hline 43 & K66 & Activities auxiliary to financial services and insurance activities \\
\hline 44 & L68 & Real estate activities \\
\hline 45 & M69_M70 & Legal and accounting activities; activities of head offices; management consultancy activities \\
\hline 46 & M71 & Architectural and engineering activities; technical testing and analysis \\
\hline 47 & M72 & Scientific research and development \\
\hline 48 & M73 & Advertising and market research \\
\hline 49 & M74_M75 & Other professional, scientific and technical activities; veterinary activities \\
\hline 50 & N & Administrative and support service activities \\
\hline 51 & O84 & Public administration and defense; compulsory social security \\
\hline 52 & P85 & Education \\
\hline 53 & Q & Human health and social work activities \\
\hline 54 & R_S & Other service activities \\
\hline 55 & $\mathrm{~T}$ & $\begin{array}{l}\text { Activities of households as employers; undifferentiated goods- and services-producing } \\
\text { activities of households for own use }\end{array}$ \\
\hline 56 & U & Activities of extraterritorial organizations and bodies \\
\hline
\end{tabular}

Source: European Commission (2008). 
Table 7 Exports to the UK by country

\begin{tabular}{|c|c|c|c|c|c|}
\hline \multirow[t]{2}{*}{ Country } & \multirow{2}{*}{$\begin{array}{l}\text { Exports to UK } \\
\text { (Million USD) }\end{array}$} & \multirow{2}{*}{$\begin{array}{l}\text { Total exports } \\
\text { (Million USD) }\end{array}$} & \multirow{2}{*}{$\begin{array}{l}\text { Total output } \\
\text { (Million USD) }\end{array}$} & \multicolumn{2}{|c|}{ Share of exports to UK } \\
\hline & & & & $\begin{array}{l}\text { In total exports } \\
\text { (\%) }\end{array}$ & $\begin{array}{l}\text { In total output } \\
(\%)\end{array}$ \\
\hline AUS & 3,736 & 287,162 & $2,723,737$ & 1.30 & 0.14 \\
\hline AUT & 5,452 & 210,995 & 809,631 & 2.58 & 0.67 \\
\hline BEL & 27,883 & 383,014 & $1,110,756$ & 7.28 & 2.51 \\
\hline$B G R$ & 767 & 31,698 & 122,873 & 2.42 & 0.62 \\
\hline BRA & 4,779 & 270,263 & $4,103,502$ & 1.77 & 0.12 \\
\hline CAN & 13,649 & 563,511 & $3,252,175$ & 2.42 & 0.42 \\
\hline $\mathrm{CHE}$ & 12,649 & 352,570 & $1,398,665$ & 3.59 & 0.90 \\
\hline $\mathrm{CHN}$ & 51,850 & $2,425,464$ & $31,745,102$ & 2.14 & 0.16 \\
\hline CYP & 352 & 9,347 & 39,448 & 3.77 & 0.89 \\
\hline CZE & 6,825 & 161,570 & 492,772 & 4.22 & 1.38 \\
\hline DEU & 103,347 & $1,682,253$ & $7,066,741$ & 6.14 & 1.46 \\
\hline DNK & 10,686 & 170,293 & 614,582 & 6.28 & 1.74 \\
\hline ESP & 21,498 & 389,005 & $2,567,905$ & 5.53 & 0.84 \\
\hline EST & 458 & 18,266 & 54,483 & 2.50 & 0.84 \\
\hline FIN & 4288 & 100,453 & 513,658 & 4.27 & 0.83 \\
\hline FRA & 60,107 & 75,9654 & $5,020,134$ & 7.91 & 1.20 \\
\hline GRC & 1779 & 5,6261 & 375,244 & 3.16 & 0.47 \\
\hline HRV & 548 & 23,269 & 97,419 & 2.35 & 0.56 \\
\hline HUN & 4521 & 116,445 & 284,430 & 3.88 & 1.59 \\
\hline IDN & 2056 & 210,599 & $1,714,343$ & 0.98 & 0.12 \\
\hline IND & 12,221 & 369,456 & 398,3527 & 3.31 & 0.31 \\
\hline IRL & 37,295 & 262,751 & 509,477 & 14.19 & 7.32 \\
\hline ITA & 33,780 & 588,585 & $4,075,402$ & 5.74 & 0.83 \\
\hline JPN & 9647 & 817,514 & $8,668,736$ & 1.18 & 0.11 \\
\hline KOR & 7848 & 697,935 & $3,403,854$ & 1.12 & 0.23 \\
\hline LTU & 1266 & 32,723 & 85,668 & 3.87 & 1.48 \\
\hline LUX & 3209 & 118,439 & 211,968 & 2.71 & 1.51 \\
\hline LVA & 669 & 14,719 & 64,726 & 4.54 & 1.03 \\
\hline MEX & 2094 & 368,185 & $2,130,489$ & 0.57 & 0.10 \\
\hline MLT & 3914 & 13,420 & 28,915 & 29.16 & 13.53 \\
\hline NLD & 43,525 & 575,068 & $1,671,177$ & 7.57 & 2.60 \\
\hline NOR & 25,676 & 188,131 & 835,079 & 13.65 & 3.07 \\
\hline POL & 14,176 & 251,642 & $1,105,444$ & 5.63 & 1.28 \\
\hline PRT & 3805 & 76,633 & 414,281 & 4.97 & 0.92 \\
\hline $\mathrm{ROU}$ & 2160 & 77,648 & 398,280 & 2.78 & 0.54 \\
\hline RUS & 9321 & 493,789 & $3,381,079$ & 1.89 & 0.28 \\
\hline SVK & 4635 & 82,119 & 229,289 & 5.64 & 2.02 \\
\hline SVN & 574 & 30,812 & 94,238 & 1.86 & 0.61 \\
\hline SWE & 12,119 & 235,354 & $1,018,189$ & 5.15 & 1.19 \\
\hline TUR & 12,805 & 249,783 & $1,494,428$ & 5.13 & 0.86 \\
\hline TWN & 4896 & 369,923 & $1,220,629$ & 1.32 & 0.40 \\
\hline USA & 73,796 & $1,927,091$ & $30,971,023$ & 3.83 & 0.24 \\
\hline
\end{tabular}

Source: World Input-Output Database, intermediate and final use in destination country, data for 2014, own calculations 
Table 8 Industry-specific tariffs, elasticities, non-tariff trade barriers, and reductions in trade volumes $(\mathrm{A}-\mathrm{F})$

\begin{tabular}{|c|c|c|c|c|c|c|c|}
\hline No. & NACE Code & $\begin{array}{l}\text { Tariff } \\
\text { Final (\%) }\end{array}$ & $\begin{array}{l}\text { Tariff } \\
\text { Intermediate (\%) }\end{array}$ & Elasticity & $\begin{array}{l}\text { MFN } \\
\text { NTB (\%) }\end{array}$ & $\begin{array}{l}\text { Reduction } \\
\text { Final (\%) }\end{array}$ & $\begin{array}{l}\text { Reduction } \\
\text { Intermediate (\%) }\end{array}$ \\
\hline 1 & $\mathrm{~A} 01$ & 7.8 & 1.0 & 1.96 & 47.0 & 47.3 & 33.9 \\
\hline 2 & $\mathrm{~A} 02$ & 10.4 & 0.2 & 1.87 & 30.0 & 42.5 & 23.5 \\
\hline 3 & A03 & 10.0 & 4.2 & 3.58 & 3.0 & 38.7 & 17.9 \\
\hline 4 & B & 0.0 & 0.0 & 3.58 & 3.0 & 2.9 & 2.9 \\
\hline 5 & C10-C12 & 18.7 & 11.2 & 1.63 & 34.0 & 55.9 & 43.6 \\
\hline 6 & C13-C15 & 9.9 & 6.2 & 3.58 & 10.0 & 44.5 & 31.3 \\
\hline 7 & C16 & 1.6 & 2.2 & 3.58 & 8.0 & 13.1 & 15.3 \\
\hline 8 & $\mathrm{C} 17$ & 1.6 & 0.0 & 1.04 & 33.0 & 26.5 & 24.8 \\
\hline 9 & $\mathrm{C} 18$ & 0.0 & 0.3 & 2.04 & 3.0 & 2.9 & 3.5 \\
\hline 10 & C19 & 0.0 & 2.4 & 6.04 & 6.0 & 5.7 & 20.2 \\
\hline 11 & C2O & 2.3 & 4.8 & 3.78 & 19.0 & 24.7 & 34.1 \\
\hline 12 & C21 & 0.0 & 0.7 & 7.63 & 17.0 & 14.5 & 19.9 \\
\hline 13 & C22 & 5.8 & 5.3 & 2.82 & 28.0 & 38.2 & 36.8 \\
\hline 14 & $\mathrm{C} 23$ & 10.1 & 3.1 & 1.42 & 35.0 & 40.3 & 30.3 \\
\hline 15 & C24 & 0.0 & 2.2 & 4.72 & 14.0 & 12.3 & 22.7 \\
\hline 16 & $C 25$ & 3.1 & 2.8 & 1.84 & 35.0 & 31.6 & 31.1 \\
\hline 17 & C26 & 2.5 & 1.4 & 5.73 & 8.0 & 21.7 & 15.4 \\
\hline 18 & $C 27$ & 2.7 & 2.5 & 6.42 & 14.0 & 29.6 & 28.3 \\
\hline 19 & C28 & 1.7 & 1.9 & 7.51 & 8.0 & 20.2 & 21.7 \\
\hline 20 & C29 & 10.0 & 5.9 & 4.39 & 19.0 & 59.9 & 41.9 \\
\hline 21 & C30 & 5.2 & 3.0 & 5.17 & 9.0 & 35.1 & 23.8 \\
\hline 22 & C31-C32 & 1.5 & 1.3 & 3.42 & 2.0 & 7.1 & 6.4 \\
\hline 23 & C33 & 0.0 & 0.0 & 1.56 & 117.0 & 53.9 & 53.9 \\
\hline 24 & D35 & 0.0 & 0.0 & 1.56 & 68.0 & 40.5 & 40.5 \\
\hline 25 & E36 & 0.0 & 0.0 & 1.56 & 3.0 & 2.9 & 2.9 \\
\hline 26 & E37-E39 & 0.0 & 0.0 & 1.56 & 56.0 & 35.9 & 35.9 \\
\hline 27 & $\mathrm{~F}$ & 0.0 & 0.0 & 1.56 & 74.0 & 42.5 & 42.5 \\
\hline
\end{tabular}

Source:Tariffs $\left(\tau^{\ell}\right)$ from Cappariello et al. (2018), Table B.8, elasticities $\left(\epsilon^{\ell}\right)$ and ad-valorem non-tariff trade barrier $\left(\mu^{\ell}\right)$ under WTO rule (MFN NTB) from Cappariello et al. (2020), Table 4. MFN NTB denotes by how much trade is inflated in the Single Market compared to non-EU. Reduction in trade calculated as $\left(\epsilon^{\ell} \times \tau^{\ell}+\frac{\mu^{\ell}}{1+\mu^{\ell}}\right)$ 
Table 9 Industry-specific tariffs, elasticities, non-tariff trade barriers, and reductions in trade volumes $(\mathrm{G}-\mathrm{U})$

\begin{tabular}{|c|c|c|c|c|c|c|c|}
\hline No. & NACE code & $\begin{array}{l}\text { Tariff } \\
\text { Final (\%) }\end{array}$ & $\begin{array}{l}\text { Tariff } \\
\text { Intermediate (\%) }\end{array}$ & Elasticity & $\begin{array}{l}\text { MFN } \\
\text { NTB (\%) }\end{array}$ & $\begin{array}{l}\text { Reduction } \\
\text { Final (\%) }\end{array}$ & $\begin{array}{l}\text { Reduction } \\
\text { Intermediate (\%) }\end{array}$ \\
\hline 28 & G45 & 0.0 & 0.0 & 1.56 & 113.0 & 53.1 & 53.1 \\
\hline 29 & G46 & 0.0 & 0.0 & 1.56 & 94.0 & 48.5 & 48.5 \\
\hline 30 & G47 & 0.0 & 0.0 & 1.56 & 117.0 & 53.9 & 53.9 \\
\hline 31 & $\mathrm{H} 49$ & 0.0 & 0.0 & 1.56 & 50.0 & 33.3 & 33.3 \\
\hline 32 & $\mathrm{H} 50$ & 0.0 & 0.0 & 1.56 & 74.0 & 42.5 & 42.5 \\
\hline 33 & H51 & 0.0 & 0.0 & 1.56 & 29.0 & 22.5 & 22.5 \\
\hline 34 & H52 & 0.0 & 0.0 & 1.56 & 18.0 & 15.3 & 15.3 \\
\hline 35 & H53 & 0.0 & 0.0 & 1.56 & 44.0 & 30.6 & 30.6 \\
\hline 36 & I & 0.0 & 0.0 & 1.56 & 45.0 & 31.0 & 31.0 \\
\hline 37 & J58 & 0.0 & 0.0 & 1.56 & 21.0 & 17.4 & 17.4 \\
\hline 38 & J59-J60 & 0.0 & 0.0 & 1.56 & 21.0 & 17.4 & 17.4 \\
\hline 39 & $J 61$ & 0.0 & 0.0 & 1.56 & 15.0 & 13.0 & 13.0 \\
\hline 40 & J62-J63 & 0.0 & 0.0 & 1.56 & 72.0 & 41.9 & 41.9 \\
\hline 41 & K64 & 0.0 & 0.0 & 1.56 & 65.0 & 39.4 & 39.4 \\
\hline 42 & K65 & 0.0 & 0.0 & 1.56 & 45.0 & 31.0 & 31.0 \\
\hline 43 & K66 & 0.0 & 0.0 & 1.56 & 55.0 & 35.5 & 35.5 \\
\hline 44 & L68 & 0.0 & 0.0 & 1.56 & 41.0 & 29.1 & 29.1 \\
\hline 45 & M69-M70 & 0.0 & 0.0 & 1.56 & 23.0 & 18.7 & 18.7 \\
\hline 46 & M71 & 0.0 & 0.0 & 1.56 & 99.0 & 49.7 & 49.7 \\
\hline 47 & M72 & 0.0 & 0.0 & 1.56 & 37.0 & 27.0 & 27.0 \\
\hline 48 & M73 & 0.0 & 0.0 & 1.56 & 18.0 & 15.3 & 15.3 \\
\hline 49 & M74-M75 & 0.0 & 0.0 & 1.56 & 57.0 & 36.3 & 36.3 \\
\hline 50 & $N$ & 0.0 & 0.0 & 1.56 & 28.0 & 21.9 & 21.9 \\
\hline 51 & O84 & 0.0 & 0.0 & 1.56 & 28.0 & 21.9 & 21.9 \\
\hline 52 & P85 & 0.0 & 0.0 & 1.56 & 58.0 & 36.7 & 36.7 \\
\hline 53 & Q & 0.0 & 0.0 & 1.56 & 32.0 & 24.2 & 24.2 \\
\hline 54 & $\mathrm{R}-\mathrm{S}$ & 0.0 & 0.0 & 1.56 & 119.0 & 54.3 & 54.3 \\
\hline 55 & $\mathrm{~T}$ & 0.0 & 0.0 & 1.56 & 45.0 & 31.0 & 31.0 \\
\hline 56 & $U$ & 0.0 & 0.0 & 1.56 & 28.0 & 21.9 & 21.9 \\
\hline
\end{tabular}

Source: Tariffs $\left(\tau_{y}^{\ell}\right.$ and $\left.\tau_{x}^{\ell}\right)$ from Cappariello et al. (2018), Table B.8, elasticities $\left(\epsilon^{\ell}\right)$ and ad-valorem non-tariff trade barrier $\left(\mu^{\ell}\right)$ under WTO rule (MFN NTB) from Cappariello et al. (2020), Table 4. MFN NTB denotes by how much trade is inflated in the Single Market compared to non-EU. Reduction in trade calculated as $\left(\epsilon^{\ell} \times \tau^{\ell}+\frac{\mu^{\ell}}{1+\mu^{\ell}}\right)$ 
Table 10 Decline in UK import demand for final goods from the EU (no-deal Brexit) by country

\begin{tabular}{|c|c|c|}
\hline \multirow[t]{2}{*}{ Country } & \multicolumn{2}{|l|}{ Reduction in exports to UK } \\
\hline & In relation to all exports (in \%) & $\begin{array}{l}\text { In relation to } \\
\text { gross output } \\
\text { (in \%) }\end{array}$ \\
\hline MLT & 49.51 & 4.25 \\
\hline $\mathrm{IRL}$ & 45.09 & 1.82 \\
\hline BEL & 42.76 & 0.46 \\
\hline SVK & 39.66 & 0.44 \\
\hline DEU & 43.59 & 0.29 \\
\hline NLD & 36.73 & 0.29 \\
\hline DNK & 38.70 & 0.28 \\
\hline CZE & 40.24 & 0.26 \\
\hline $\mathrm{POL}$ & 38.60 & 0.23 \\
\hline HUN & 35.23 & 0.22 \\
\hline ESP & 45.37 & 0.21 \\
\hline FRA & 37.70 & 0.18 \\
\hline PRT & 40.64 & 0.17 \\
\hline LUX & 35.94 & 0.15 \\
\hline CYP & 38.45 & 0.15 \\
\hline ITA & 36.36 & 0.15 \\
\hline SWE & 28.73 & 0.11 \\
\hline LTU & 21.82 & 0.11 \\
\hline AUT & 36.19 & 0.10 \\
\hline ROU & 36.37 & 0.09 \\
\hline HRV & 40.69 & 0.09 \\
\hline BGR & 32.06 & 0.07 \\
\hline SVN & 27.95 & 0.06 \\
\hline GRC & 36.01 & 0.06 \\
\hline EST & 30.28 & 0.06 \\
\hline LVA & 28.05 & 0.06 \\
\hline FIN & 20.55 & 0.04 \\
\hline Total & 40.64 & 0.25 \\
\hline
\end{tabular}

Source: World Input-Output Database and own calculations 
Table 11 Potential employment effects of a decline in UK import demand for final goods from the EU (no-deal Brexit) by country and industry (30 most affected country-industry combinations)

\begin{tabular}{|c|c|c|c|c|c|c|c|}
\hline No. & Country & Industry & $\begin{array}{l}\text { Direct } \\
(1000 \\
\text { pers.) }\end{array}$ & $\begin{array}{l}\text { Indirect } \\
\text { (1000 pers.) }\end{array}$ & Sum (1000 pers.) & $\begin{array}{l}\text { Tot. Empl. } \\
\text { (1000 pers.) }\end{array}$ & Share (\%) \\
\hline 1 & DEU & 20 & 21.863 & 5.599 & 27.462 & 846 & 3.246 \\
\hline 2 & IND & 1 & 0.000 & 24.232 & 24.232 & 253,883 & 0.010 \\
\hline 3 & $\mathrm{CHN}$ & 1 & 0.000 & 15.233 & 15.233 & 175,119 & 0.009 \\
\hline 4 & DEU & 50 & 0.259 & 14.738 & 14.997 & 3,010 & 0.498 \\
\hline 5 & POL & 1 & 2.505 & 12.482 & 14.987 & 1,640 & 0.914 \\
\hline 6 & DEU & 29 & 6.997 & 7.271 & 14.268 & 1,878 & 0.760 \\
\hline 7 & DEU & 5 & 9.557 & 2.910 & 12.466 & 927 & 1.345 \\
\hline 8 & $\mathrm{CHN}$ & 29 & 0.000 & 11.966 & 11.966 & 79,834 & 0.015 \\
\hline 9 & $\mathbb{I R L}$ & 1 & 10.196 & 0.868 & 11.064 & 80 & 13.830 \\
\hline 10 & BRA & 1 & 0.000 & 10.959 & 10.959 & 13,128 & 0.083 \\
\hline 11 & IDN & 1 & 0.000 & 10.363 & 10.363 & 40,597 & 0.026 \\
\hline 12 & $\mathrm{POL}$ & 30 & 6.107 & 4.164 & 10.271 & 1,430 & 0.718 \\
\hline 13 & FRA & 29 & 5.449 & 4.243 & 9.691 & 1,110 & 0.873 \\
\hline 14 & ESP & 1 & 5.340 & 3.983 & 9.324 & 667 & 1.398 \\
\hline 15 & ITA & 6 & 5.691 & 3.475 & 9.166 & 515 & 1.780 \\
\hline 16 & $\mathrm{IRL}$ & 5 & 8.411 & 0.109 & 8.521 & 54 & 15.779 \\
\hline 17 & FRA & 50 & 0.814 & 7.520 & 8.334 & 2,059 & 0.405 \\
\hline 18 & FRA & 1 & 1.705 & 6.500 & 8.205 & 715 & 1.148 \\
\hline 19 & DEU & 28 & 0.979 & 7.121 & 8.100 & 824 & 0.983 \\
\hline 20 & FRA & 5 & 6.047 & 2.027 & 8.074 & 607 & 1.330 \\
\hline 21 & USA & 50 & 0.000 & 7.792 & 7.792 & 12,808 & 0.061 \\
\hline 22 & $\mathrm{CHN}$ & 6 & 0.000 & 7.481 & 7.481 & 32,739 & 0.023 \\
\hline 23 & ITA & 1 & 1.192 & 6.255 & 7.447 & 839 & 0.888 \\
\hline 24 & DEU & 16 & 1.213 & 6.214 & 7.427 & 901 & 0.824 \\
\hline 25 & DEU & 1 & 1.244 & 6.111 & 7.355 & 606 & 1.214 \\
\hline 26 & IND & 6 & 0.000 & 7.291 & 7.291 & 21,927 & 0.033 \\
\hline 27 & DEU & 30 & 0.629 & 6.569 & 7.199 & 3,209 & 0.224 \\
\hline 28 & DEU & 19 & 3.672 & 3.496 & 7.168 & 1,129 & 0.635 \\
\hline 29 & POL & 5 & 4.797 & 2.149 & 6.946 & 541 & 1.284 \\
\hline 30 & DEU & 45 & 0.028 & 6.233 & 6.261 & 1,287 & 0.487 \\
\hline
\end{tabular}

Ordered by absolute employment effect. Source: World Input-Output Database, data for 2014, own calculations 
Table 12 Potential employment effects of a decline in UK import demand for final goods from the EU (no-deal Brexit) by NUTS-2 region (30 most affected regions)

\begin{tabular}{|c|c|c|c|c|c|c|}
\hline No. & NUTS-2 & Country & Region & $\begin{array}{l}\text { Affected } \\
\text { persons (1000 } \\
\text { pers.) }\end{array}$ & $\begin{array}{l}\text { Total } \\
\text { employment } \\
\text { (1000 pers.) }\end{array}$ & $\begin{array}{l}\text { Share of } \\
\text { affected } \\
\text { persons (\%) }\end{array}$ \\
\hline 1 & MT0 & MLT & Malta & 6.478 & 190 & 3.409 \\
\hline 2 & IE4 & $\mid R L$ & Northern and Western & 8.009 & 335 & 2.385 \\
\hline 3 & IE5 & $\mathrm{IRL}$ & Southern & 13.961 & 634 & 2.202 \\
\hline 4 & IE6 & $\mathrm{IRL}$ & Eastern and Midland & 13.553 & 944 & 1.436 \\
\hline 5 & BE25 & BEL & Prov. West-Vlaanderen & 3.477 & 503 & 0.691 \\
\hline 6 & $\mathrm{BE} 22$ & BEL & Prov. Limburg (BE) & 2.401 & 362 & 0.662 \\
\hline 7 & BE23 & BEL & Prov. Oost-Vlaanderen & 4.293 & 650 & 0.660 \\
\hline 8 & BE21 & BEL & Prov. Antwerpen & 5.005 & 762 & 0.656 \\
\hline 9 & BE34 & BEL & Prov. Luxembourg (BE) & 0.717 & 113 & 0.632 \\
\hline 10 & BE32 & BEL & Prov. Hainaut & 2.726 & 455 & 0.598 \\
\hline 11 & BE31 & BEL & Prov. Brabant wallon & 0.960 & 165 & 0.581 \\
\hline 12 & BE24 & BEL & Prov. Vlaams-Brabant & 2.859 & 494 & 0.579 \\
\hline 13 & BE33 & BEL & Prov. Liège & 2.286 & 397 & 0.575 \\
\hline 14 & SK2 & SVK & Západné Slovensko & 4.479 & 785 & 0.570 \\
\hline 15 & CZ5 & CZE & Severovýchod & 3.986 & 717 & 0.556 \\
\hline 16 & PL92 & $\mathrm{POL}$ & Mazowiecki regionalny & 6.256 & 1,136 & 0.551 \\
\hline 17 & CZ7 & CZE & Strední Morava & 3.113 & 566 & 0.549 \\
\hline 18 & PL72 & POL & Swietokrzyskie & 3.077 & 562 & 0.547 \\
\hline 19 & PL41 & POL & Wielkopolskie & 7.076 & 1,310 & 0.540 \\
\hline 20 & $\mathrm{BE} 10$ & BEL & Région de Bruxelles-Capitale & 2.417 & 448 & 0.538 \\
\hline 21 & BE35 & BEL & Prov. Namur & 1.035 & 193 & 0.535 \\
\hline 22 & PL82 & $\mathrm{POL}$ & Podkarpackie & 4.076 & 763 & 0.534 \\
\hline 23 & CZ8 & CZE & Moravskoslezsko & 2.994 & 562 & 0.532 \\
\hline 24 & PL84 & $\mathrm{POL}$ & Podlaskie & 2.408 & 453 & 0.531 \\
\hline 25 & CZ3 & CZE & Jihozápad & 3.165 & 596 & 0.531 \\
\hline 26 & PL71 & $\mathrm{POL}$ & Lódzkie & 6.638 & 1,256 & 0.528 \\
\hline 27 & PL61 & $\mathrm{POL}$ & Kujawsko-Pomorskie & 4.000 & 767 & 0.521 \\
\hline 28 & PL81 & $\mathrm{POL}$ & Lubelskie & 5.014 & 966 & 0.519 \\
\hline 29 & PL52 & $\mathrm{POL}$ & Opolskie & 1.835 & 355 & 0.516 \\
\hline 30 & CZ6 & CZE & Jihovýchod & 4.178 & 813 & 0.513 \\
\hline
\end{tabular}

Ordered by share of affected persons. Source: World Input-Output Database, Eurostat (regional employment data) and own calculations 
Table 13 Potential employment effects of a decline in UK import demand for final goods from the EU (no-deal Brexit) in German counties (30 most affected counties)

\begin{tabular}{|c|c|c|c|c|}
\hline No. & County & $\begin{array}{l}\text { Affected persons } \\
\text { (1000 pers.) }\end{array}$ & $\begin{array}{l}\text { Total employment } \\
\text { (1000 pers.) }\end{array}$ & $\begin{array}{l}\text { Share of } \\
\text { affected } \\
\text { persons (\%) }\end{array}$ \\
\hline 1 & Dingolfing-Landau & 449 & 67,339 & 0.667 \\
\hline 2 & Wolfsburg & 835 & 127,082 & 0.657 \\
\hline 3 & Tuttlingen & 517 & 83,025 & 0.622 \\
\hline 4 & Salzgitter & 343 & 56,968 & 0.602 \\
\hline 5 & Enzkreis & 464 & 79,546 & 0.583 \\
\hline 6 & Germersheim & 340 & 58,924 & 0.577 \\
\hline 7 & Erlangen-Höchstadt & 345 & 59,896 & 0.577 \\
\hline 8 & Hohenlohekreis & 397 & 69,060 & 0.574 \\
\hline 9 & Olpe & 441 & 76,972 & 0.572 \\
\hline 10 & Ingolstadt & 675 & 118,072 & 0.572 \\
\hline 11 & Heilbronn & 940 & 164,491 & 0.571 \\
\hline 12 & Coburg & 212 & 37,232 & 0.571 \\
\hline 13 & Biberach & 601 & 105,286 & 0.570 \\
\hline 14 & Rastatt & 640 & 113,006 & 0.566 \\
\hline 15 & Kronach & 188 & 33,395 & 0.564 \\
\hline 16 & Donau-Ries & 442 & 79,760 & 0.554 \\
\hline 17 & Märkischer Kreis & 1182 & 214,231 & 0.552 \\
\hline 18 & Unterallgäu & 370 & 67,096 & 0.551 \\
\hline 19 & Böblingen & 1223 & 222,007 & 0.551 \\
\hline 20 & Neustadt a.d.Waldnaab & 209 & 38,039 & 0.548 \\
\hline 21 & Rottweil & 409 & 74,578 & 0.548 \\
\hline 22 & Hof & 261 & 47,707 & 0.546 \\
\hline 23 & Haßberge & 213 & 39,142 & 0.544 \\
\hline 24 & Main-Spessart & 330 & 60,787 & 0.544 \\
\hline 25 & Saale-Orla-Kreis & 219 & 40,305 & 0.543 \\
\hline 26 & Ludwigshafen am Rhein & 669 & 123,478 & 0.542 \\
\hline 27 & Schweinfurt & 354 & 65,896 & 0.538 \\
\hline 28 & Wartburgkreis & 281 & 52,533 & 0.535 \\
\hline 29 & Bodenseekreis & 640 & 120,470 & 0.531 \\
\hline 30 & Lindau (Bodensee) & 227 & 42,759 & 0.531 \\
\hline
\end{tabular}

Ordered by share of affected persons. Source: World Input-Output Database, data for 2014, VGR der Länder (regional employment data for 2014 as of August 2017) and own calculations

\section{Acknowledgements}

We thank Martina Kämpfe, Axel Lindner and three anonymous reviewers for helpful comments.

\section{Authors' contributions}

Both authors have developed the research idea and the concept of the project together. Both authors have worked on the computer code for the calculations and have written parts of the manuscript. Both authors read and approved the final manuscript.

\section{Funding}

This project has been funded by the regular budget of the Halle Institute for Economic Research (IWH).

Availability of data and materials

The data used for this project are publicly available and are described in section 2 Data and methodology.

\section{Declarations}

\section{Competing interests}

The authors declare that they have no competing interests. 


\section{Author details}

${ }^{1}$ Halle Institute for Economic Research (IWH), Kleine Maerkerstrasse 8, 06108 Halle (Saale), Germany. ${ }^{2}$ Martin Luther University Halle-Wittenberg, 06108 Halle (Saale), Germany.

Received: 21 May 2019 Revised: 28 June 2021 Accepted: 1 July 2021

Published online: 12 July 2021

\section{References}

Aichele R, Felbermayr G (2015) Kosten und Nutzen eines Austritts des Vereinigten Königreichs aus der Europäischen Union. Global Economic Dynamics, BertelsmannStiftung, Gütersloh

Amiti M, Redding SJ, Weinstein D (2019) The impact of the 2018 trade war on U.S. prices and welfare. NBER Working Paper 25672, National Bureau of Economic Research, Cambridge

Bisciari P (2019) A survey of the long-term impact of Brexit on the UK and the EU27 economies. NBB Working Paper 366, National Bank of Belgium, Brussels

Bloom N, Bunn P, Chen S, Mizen P, Smietanka P, Thwaites G (2019) The impact of Brexit on UK firms. NBER Working Paper 26218, National Bureau of Economic Research, Cambridge

Broadbent B, DiPace F, Drechsel T, Harrison R, Tenreyro S, (2019) The Brexit vote, productivity growth and macroeconomic adjustments in the United Kingdom. CEPR Discussion Paper 13993, Centre for Economic Policy Research, London

Campos RG, Timini J (2019) An estimation of the effects of Brexit on trade and migration. Banco de Espana Occasional Paper 1912, Banco de Espana, Madrid

Cappariello R, Damjanovic M, Mancini M, Vergara Caffarelli F (2018) EU-UK global value chain trade and the indirect costs of Brexit. Occasional Paper 468, Bank of Italy

Cappariello R, Gunnella V, Franco-Bedoya S, Ottaviano GIP (2020) Rising protectionism and global value chains: Quantifying the general equilibrium effects. ECB Working Paper 2360, European Central Bank, Frankfurt (Main)

Chen W, Los B, McCann P, Ortega-Argilés R, Thissen M, van Oort F (2018) The continental divide? Economic exposure to Brexit in regions and countries on both sides of the channel. Papers Reg Sci 97(1):25-54

Cumming DJ, Zahra SA (2016) International business and entrepreneurship implications of Brexit. Br J Manag 27(4):687-692

Dhingra S, Huang H, Ottaviano G, Pessoa JP, Sampson T, Reenen JV (2017a) The costs and benefits of leaving the EU: trade effects. Econ Policy 32:651-705

Dhingra S, Machin S, Overman H (2017b) Local economic effects of Brexit. Natl Inst Econ Rev 242(1):R24-R36

Dhingra S, Ottaviano G, Rappoport V, Sampson T, Thomas C (2018) UK trade and FDl: a post-Brexit perspective. Papers Reg Sci 97(1):9-24

European Commission, 2008. NACE Rev. 2 Statistical classification of economic activities. Eurostat Methodologies and Working Papers

Feenstra RC, Sasahara A (2018) The 'china shock', exports and U.S. employment: A global input-output analysis. Rev Int Econ 26:1053-1083

Felbermayr G, Gröschl J, Heiland I, Braml M, Steininger M (2017) Ökonomische Effekte eines Brexit auf die deutsche und europäische Wirtschaft. ifo Forschungsbericht 85, ifo Institut, München

Furceri D, Hannan SA, Ostry JD, Rose AK (2018) Macroeconomic consequences of tariffs. Working Paper 25402, National Bureau of Economic Research

Hantzsche A, Kara A, Young G (2018) The Economic Effects of the Government's Proposed Brexit Deal. National Institute of Economic and Social Research, London

IJtsma, P., Levell, P., Los, B., Timmer, M. P. (2018) The UK's participation in global value chains and its implications for postBrexit trade policy. Fiscal Studies 39(4):651-683

Kierzenkowskii R, Paini N, Rusticellii E, Zwart S (2016) The economic consequences of Brexit: A taxing decision. OECD Economic Policy Papers 16, Organization for Economic Cooperation and Development, Paris

Los B (2017) Input-output analysis of international trade. In: ten Raa T (ed) Handbook of input-output analysis. Edward Elgar, Cheltenham and Northampton, pp 277-328

Los B, McCann P, Springford J, Thissen M (2017) The mismatch between local voting and the local economic consequences of Brexit. Reg Stud 51(5):786-799

Los B, Timmer MP, de Vries GJ (2015) How important are exports for job growth in China?: A demand side analysis. J Comp Econ 43(1):19-32

Miller RE, Blair PD (2009) Input-output analysis. Foundations and extensions, 2nd edn. Cambridge University Press, New York and Cambridge

Powdthavee N, Plagnol AC, Frijters P, Clark AE (2019) Who got the Brexit blues? The effect of Brexit on subjective wellbeing in the UK. Economica 86(343):471-494

Timmer MP, Dietzenbacher E, Los B, Stehrer R, de Vries GJ (2015) An illustrated user guide to the World-Input-Output Database: the case of global automotive production. Rev Int Econ 23:575-605

Timmer, M. P., Los, B., Stehrer, R., de Vries, G. J., 2016. An anatomy of the global trade slowdown based on the WIOD 2016 release. Groningen Growth and Development Centre Research Memorandum 162, University of Groningen, Groningen

Vandenbussche, H., Connell, W., Simons, W., 2019. Global value chains, trade shocks and jobs: An application to Brexit. CESifo Working Paper 7473, Munich Society for the Promotion of Economic Research - CESifo GmbH, Munich

\section{Publisher's Note}

Springer Nature remains neutral with regard to jurisdictional claims in published maps and institutional affiliations. 